\title{
Occurrence of multiple sclerosis in the north and south of New Zealand
}

\author{
D C G SKEGG, ${ }^{*}$ P A CORWIN, ${ }^{*}$ R S CRAVEN,, J A MALLOCH, $\dagger$ M POLLOCK
}

From the Department of Preventive and Social Medicine, University of Otago, ${ }^{*}$ Dunedin, Department of Neurology, Waikato Hospital, $\uparrow$ Hamilton, and the Division of Neurology, Department of Medicine $\ddagger$ University of Otago, Dunedin, New Zealand

SUMMARY An impression that multiple sclerosis is commoner in southern parts of New Zealand than in the north has never been tested rigorously. Identical methods were used to determine the prevalence and incidence of multiple sclerosis in two regions: the Waikato (in the North Island) and Otago and Southland (in the South Island). No cases were found in Maoris, while the expected number was $11 \cdot 7$. The prevalence rate of multiple sclerosis (excluding possible cases) in non-Maoris was 24 per 100,000 in the northern region and 69 per 100,000 in the south. The incidence rate was also more than twice as high in the southern region. These findings are considered in relation to genetic and environmental hypotheses about the aetiology of multiple sclerosis.

In several parts of the world the prevalence of multiple sclerosis increases with distance from the equator, though this relation to latitude is not found consistently. ${ }^{1-3}$ Most studies have been carried out in the Northern Hemisphere and the need for more information from the Southern Hemisphere has been stressed. ${ }^{45}$

In Australia, McCall et $a l^{6}$ found that the prevalence of multiple sclerosis in Hobart was higher than in Perth or Newcastle. Using routine data about deaths and hospital admissions, Acheson ${ }^{7}$ suggested that multiple sclerosis was commoner in the South Island of New Zealand than in the North Island. Prevalence surveys in Wellington ${ }^{8}$ and Christchurch ${ }^{9}$ showed no appreciable difference, but this could have been due to the small variation in latitude $\left(2^{\circ} 15^{\prime}\right)$ or to methodological differences between the two studies. We, therefore, studied the occurrence of multiple sclerosis in comparable populations living in northern and southern parts of New Zealand. One of these regions lies further south than any area previously surveyed for multiple sclerosis.

Address for reprint requests: Professor D C G Skegg, Department of Preventive and Social Medicine, University of Otago Medical School, Dunedin, New Zealand.

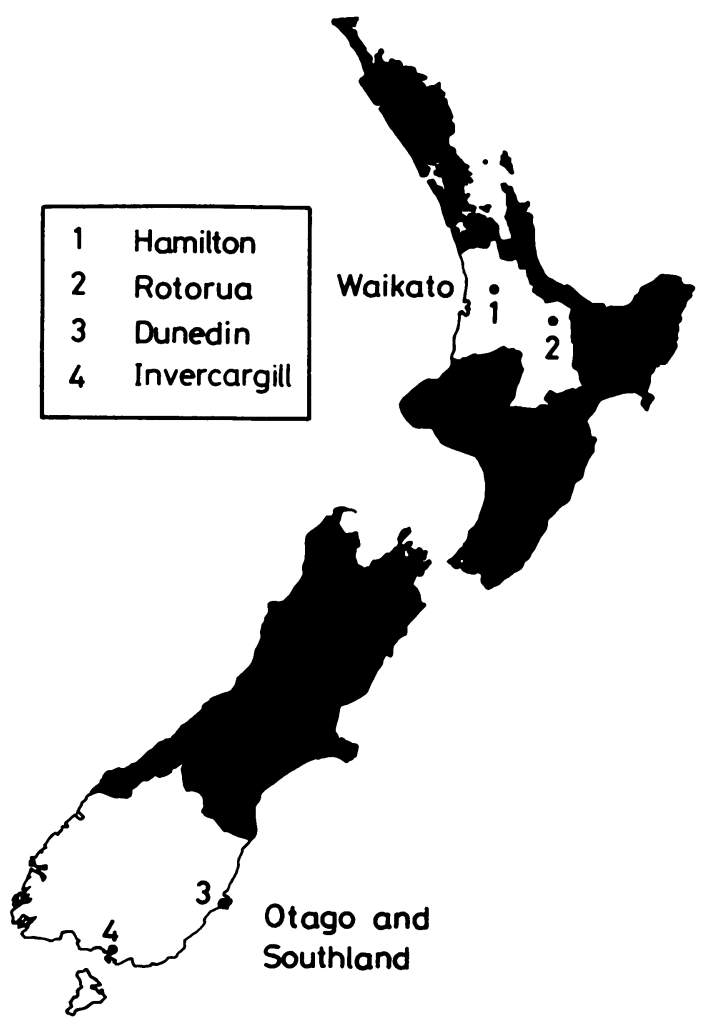

Fig Map of New Zealand showing the Waikato Hospital Board are and Otago and Southland. 
Table 1 Number of patients in the two regions on the prevalence day, according to diagnostic category

\begin{tabular}{llccc}
\hline & \multicolumn{2}{l}{ Waikato } & \multicolumn{2}{c}{ Otago-Southland } \\
\cline { 2 - 5 } Diagnostic category & No & $\%$ & No & $\%$ \\
\hline Probable multiple sclerosis & 50 & 65 & 130 & 58 \\
Early probable multiple & & & & \\
$\quad$ sclerosis & 15 & 19 & 65 & 29 \\
Possible multiple sclerosis & 12 & 16 & 31 & 14 \\
Total & 77 & 100 & 226 & 100 \\
\hline
\end{tabular}

\section{Methods}

The two regions studied (fig) were: (1) Waikato Hospital Board area, with a total population of 327,321 in 1981. The main urban areas are Hamilton (latitude $37^{\circ} 47^{\prime} \mathrm{S}$, longitude $175^{\circ} 17^{\prime} \mathrm{E}$ ) and Rotorua (latitude $38^{\circ} 09^{\prime} \mathrm{S}$, longitude $\left.176^{\circ} 15^{\prime} \mathrm{E}\right),(2)$ Otago and Southland, with a total population of 291,726 in 1981. The main urban areas are Dunedin (latitude $45^{\circ} 53^{\prime} \mathrm{S}$, longitude $170^{\circ} 31^{\prime} \mathrm{E}$ ) and Invercargill (latitude $46^{\circ} 25^{\prime} \mathrm{S}$, longitude $168^{\circ} 21^{\prime} \mathrm{E}$ ).

Both regions are mixed urban-rural areas, with considerable emphasis on farming. They are served by neurological units in Hamilton and Dunedin, respectively. It would be unusual for patients to migrate into or out of these regions for neurological treatment. We tried to ascertain every patient likely to have multiple sclerosis from the diagnostic indices of all hospitals in the two regions (searched over 20 years), other hospital indices (such as neurology department ward books), and lists of members of the Multiple Sclerosis Society. Letters were also sent to all consultant physicians and general practitioners in each area. Doctors who did not reply were sent a second letter and, if necessary, contacted by telephone. Personal and clinical data were abstracted from medical records or sought through general practitioners. Most of the patients had already been under the care of one of the neurological units but, if the information in medical records was not adequate for classification of the diagnosis, a special neurological examination of the patient was arranged.

Diagnoses were classified by strict application of the criteria of Allison and Millar, ${ }^{10}$ as modified by Alter et al. ${ }^{11}$ Although the results of modern electrophysiological tests were recorded, these were not considered in the diagnostic classification. After a pilot study, the investigators from the two centres met to discuss the criteria and to classify a sample of each other's cases. Close liaison was maintained throughout the study. At the end of the project, an independent neurologist (Dr E W Willoughby, University of Auckland) reviewed a random sample of the cases from each region: he was satisfied that the diagnostic criteria had been applied consistently.

The prevalence of multiple sclerosis was based on the number of diagnosed patients resident in each region at the time of the national population census on 24 March 1981. The average annual incidence was estimated from the number of new cases diagnosed during the previous 5 years. Census data provided the population denominators for calculation of prevalence and incidence rates. In the 1981 census, Maoris were defined as people who specified themselves as being of half or more Maori origin. ${ }^{12}$ Confidence intervals were calculated using the Poisson distribution. ${ }^{13}$

\section{Results}

On the prevalence day in 1981 , there were 77 patients with multiple sclerosis (including all diagnostic categories) in the Waikato and 226 patients in Otago and Southland. Their mean ages were 48.4 in the Waikato and 49.4 in Otago and Southland. The mean ages at onset were estimated to be 33.7 and 35.3 respectively. The average delay from onset to diagnosis was $4 \cdot 0$ years in the northern region and 3.5 years in the south.

Table 1 shows the division of cases by diagnostic category. The proportions were similar in the two regions. Although there was a higher proportion of early probable cases in Otago and Southland, this difference was not statistically significant $\left(\chi_{1}^{2}=2 \cdot 08\right.$; $\mathrm{p}>0 \cdot 10$ ).

Not one Maori patient with multiple sclerosis was found to be resident in either region on the prevalence day. Maoris comprised $15.7 \%$ of the people living in the Waikato, and $2.4 \%$ of those in Otago and Southland. Having regard to the age-structure of the Maori populations in these regions, the expected number of Maori cases was 11.7.

In calculating prevalence and incidence rates, we confined attention to the non-Maori population of each region. Table 2 shows the prevalence of different categories of multiple sclerosis. The prevalence rate was between 2.5 and 3 times higher in the southern region, whether one looked at the most reliable diagnostic category or at all cases of multiple sclerosis. Adjustment for age made no appreciable difference to these estimates (see below). The $95 \%$ confidence intervals for the prevalence (per 100,000) of probable

Table 2 Prevalence rates of multiple sclerosis in the two regions

\begin{tabular}{|c|c|c|c|c|}
\hline \multirow[b]{2}{*}{ Diagnostic category } & \multicolumn{2}{|l|}{ Waikato } & \multicolumn{2}{|c|}{ Otago-Southland } \\
\hline & No of cases & Prevalence per $100,000^{*}$ & No of cases & Prevalence per $100,000^{*}$ \\
\hline \multirow{2}{*}{$\begin{array}{l}\text { Probable multiple sclerosis } \\
\text { Probable and early probable multiple sclerosis } \\
\text { Probable and early probable and possible multiple } \\
\text { sclerosis }\end{array}$} & $\begin{array}{l}50 \\
65\end{array}$ & $\begin{array}{l}18 \cdot 1 \\
23 \cdot 6\end{array}$ & $\begin{array}{l}130 \\
195\end{array}$ & $\begin{array}{l}45.7 \\
68.5\end{array}$ \\
\hline & 77 & 27.9 & 226 & 79.4 \\
\hline
\end{tabular}

*The non-Maori population was 275,907 in the Waikato and 284,643 in Otago and Southland. 
Table 3 Prevalence of multiple sclerosis (excluding possible cases) in the Waikato, according to sex and age

\begin{tabular}{|c|c|c|c|c|c|c|}
\hline \multirow[b]{2}{*}{ Age (years) } & \multicolumn{2}{|l|}{ Males } & \multicolumn{2}{|l|}{ Females } & \multicolumn{2}{|l|}{ Both sexes } \\
\hline & No of cases & Prevalence per 100,000 & No of cases & Prevalence per 100,000 & No of cases & Prevalence per 100,000 \\
\hline $\begin{array}{l}20-29 \\
30-39 \\
40-49 \\
50-59 \\
60-69 \\
\geqslant 70 \\
\text { All ages* }\end{array}$ & $\begin{array}{r}1 \\
4 \\
7 \\
5 \\
1 \\
0 \\
18\end{array}$ & $\begin{array}{c}4 \cdot 3 \\
20 \cdot 3 \\
50 \cdot 0 \\
36 \cdot 9 \\
10 \cdot 6 \\
0 \\
12 \cdot 9(12 \cdot 7)\end{array}$ & $\begin{array}{r}2 \\
12 \\
15 \\
9 \\
8 \\
1 \\
47\end{array}$ & $\begin{array}{r}9 \cdot 0 \\
62.4 \\
108 \cdot 2 \\
72 \cdot 0 \\
79 \cdot 8 \\
11 \cdot 9 \\
34.4(34 \cdot 7)\end{array}$ & $\begin{array}{r}3 \\
16 \\
22 \\
14 \\
9 \\
1 \\
65\end{array}$ & $\begin{array}{c}6.6 \\
41 \cdot 1 \\
77 \cdot 3 \\
53 \cdot 8 \\
46.3 \\
6.9 \\
23.6(23.7)\end{array}$ \\
\hline
\end{tabular}

*The rates in parentheses are directly age-adjusted to the combined population of the two regions.

Table 4 Prevalence of multiple sclerosis (excluding possible cases) in Otago and Southland, according to sex and age

\begin{tabular}{|c|c|c|c|c|c|c|}
\hline \multirow[b]{2}{*}{ Age (years) } & \multicolumn{2}{|l|}{ Males } & \multicolumn{2}{|l|}{ Females } & \multicolumn{2}{|l|}{ Both sexes } \\
\hline & No of cases & Prevalence per 100,000 & No of cases & Prevalence per 100,000 & No of cases & Prevalence per 100,000 \\
\hline $\begin{array}{l}10-19 \\
20-29 \\
30-39 \\
40-49 \\
50-59 \\
60-69 \\
\geqslant 70 \\
\text { All ages* }\end{array}$ & $\begin{array}{r}1 \\
6 \\
12 \\
8 \\
11 \\
2 \\
8 \\
48\end{array}$ & $\begin{array}{r}3.7 \\
24 \cdot 4 \\
63 \cdot 4 \\
55 \cdot 7 \\
75 \cdot 7 \\
18 \cdot 5 \\
101 \cdot 9 \\
33 \cdot 8(34 \cdot 0)\end{array}$ & $\begin{array}{r}1 \\
14 \\
33 \\
28 \\
38 \\
26 \\
7 \\
147\end{array}$ & $\begin{array}{r}3 \cdot 8 \\
61 \cdot 5 \\
184 \cdot 2 \\
203 \cdot 9 \\
270 \cdot 0 \\
203 \cdot 6 \\
57 \cdot 7 \\
103 \cdot 0(101 \cdot 9)\end{array}$ & $\begin{array}{r}2 \\
20 \\
45 \\
36 \\
49 \\
28 \\
15 \\
195\end{array}$ & $\begin{array}{r}3 \cdot 8 \\
42 \cdot 3 \\
122 \cdot 1 \\
128 \cdot 2 \\
171 \cdot 2 \\
118.9 \\
75.0 \\
68 \cdot 5(67 \cdot 6)\end{array}$ \\
\hline
\end{tabular}

*The rates in parentheses are directly age-adjusted to the comivined population of the two regions.

and early probable multiple sclerosis were $18 \cdot 2-30 \cdot 0$ in the Waikato and 59.4-79.0 in Otago and Southland.

The sex- and age-specific prevalence rates of probable and early probable multiple sclerosis are given in tables 3 and 4 . The disease was most prevalent in people between 40 and 50 years of age in the Waikato, and between 50 and 60 in Otago and Southland. In both regions the prevalence rates were higher among females: the sex ratio of age-adjusted rates was $2 \cdot 7: 1$ in the northern region and 3.0:1 in the south.

Table 5 shows the incidence of new cases of probable and early probable multiple sclerosis diagnosed during the 5 years before 24 March 1981. The average annual incidence rate in Otago and Southland (4.8 per 100,000 ) was $2 \cdot 7$ times higher than the rate in the Waikato $(1.8$ per 100,000$)$.

\section{Discussion}

The prevalence and incidence rates of multiple sclerosis were both between 2.5 and 3 times higher in the

Table 5 Incidence of multiple sclerosis (excluding possible cases) in the two regions, 1976-1981

\begin{tabular}{lcc}
\hline & Waikato & Otago-Southland \\
\hline No of cases & 24 & 69 \\
Person-years at risk * & $1,367,060$ & $1,438,438$ \\
Annual incidence per 100,000 & $1 \cdot 8$ & $4 \cdot 8$ \\
$95 \%$ confidence interval & $1 \cdot 2-2 \cdot 7$ & $3 \cdot 7-6 \cdot 1$ \\
\hline
\end{tabular}

*Non-Maori populations estimated from the population censuses in March 1976 and March 1981. southern provinces of New Zealand than in a comparable region of the North Island. New Zealand has a relatively homogeneous society, with even standards of hospital provision and medical care. ${ }^{14}$ The differences observed were too large to be attributed to chance, and care was taken to use the same survey methods in the regions compared.

We used five sources to ascertain suspect cases, but diagnostic indices maintained by hospitals or neurologists were the first source of $88 \%$ of cases in the Waikato and $90 \%$ in Otago and Southland. From experience in meticulous surveys in New Orleans and Winnipeg, Stazio et $a l^{15}$ questioned the need to circularise doctors, or to interview and examine each patient, in studies comparing the frequency of multiple sclerosis in communities with similar medical standards. We did not examine all patients, but general practitioners were very helpful in determining the residence of patients and providing other missing information.

The prevalence rates derived here are probably under-estimates of the true prevalence in each region. First, it is impossible to discover every case of multiple sclerosis in a survey of this kind: in places where such surveys have been repeated, further patients have always come to light on the second occasion. ${ }^{1516}$ Secondly, the diagnostic criteria did not give weight to the results of electrophysiological tests such as the recording of visual evoked potentials. The advantages of this approach are that it allows comparison of our results with those of previous surveys, and that it reduces any risk that differential use of 
such tests could have distorted the comparison between the two regions.

There is often a delay of several years between the onset of multiple sclerosis and the recording of a diagnosis. To minimise under-estimation of multiple sclerosis, many workers have back-dated the prevalence day and included patients whose illnesses had started before that date (even though the diagnosis was not made until later). Others have included only patients who were diagnosed before the prevalence day. We preferred the latter approach, since estimating the actual date of onset can be extremely difficult (especially from medical records) and subject to bias. However, we also counted patients whose dates of onset were before an earlier prevalence day in March 1976. Using this approach, the ratios of prevalence rates in the two regions $(2 \cdot 9: 1$ for probable and early probable multiple sclerosis; $2 \cdot 6: 1$ for all diagnostic categories) were almost identical to those presented here.

In previous surveys, the highest prevalence rates of multiple sclerosis have generally been in the fifth decade of life. ${ }^{4}$ This was the case in the Waikato, but in Otago and Southland the highest rates were in men and women aged 50-59 years. The female-male sex ratios (2.7:1 in the northern region and 3.0:1 in the south) were considerably higher than in most studies elsewhere. ${ }^{4}$ In Hornabrook's survey in Wellington in $1968,{ }^{8}$ the sex ratio was $2 \cdot 8: 1$; in Christchurch in $1971,{ }^{9}$ the sex ratio (based on numbers of persons, with possible cases included) was 1:9:1. Relatively high sex ratios were also noted in an Australian survey. ${ }^{6}$ In a recent tabulation of mortality from multiple sclerosis in 32 countries, ${ }^{17}$ New Zealand had the highest sex ratio $(2 \cdot 0: 1)$ while Australia also had one of the highest ratios.

The absence of Maori cases, despite a substantial population of Maoris in the Waikato, confirms a clinical impression that multiple sclerosis is rare in Maori people. Hornabrook, ${ }^{8}$ who also found no cases in his Wellington survey, noted that the number of Maoris in the age groups susceptible to multiple sclerosis was small. Nevertheless, the expected number of cases (adjusted for age) in our survey was 11.7.

In interpreting the apparent rarity of multiple sclerosis in Maoris, two possible sources of bias need to be considered. First, since many New Zealand physicians believe that multiple sclerosis is very rare in Maoris, they may be less likely to make the diagnosis in a Maori. Secondly, Maoris tend to be of lower socio-economic status than Europeans; ${ }^{18}$ apart from affecting their risk of multiple sclerosis, ${ }^{1920}$ this could affect their access to specialist medical services. It should be emphasised, however, that the ethnic differences in living standards and health indices ${ }^{21}$ in New Zealand are not nearly as large as in some other countries, such as Australia or South Africa. Although these factors could influence the recorded prevalence of multiple sclerosis in Maoris, the magnitude of the ethnic difference (which is also seen in mortality data ${ }^{22}$ ) persuades us that the low risk in Maoris is real. Given the similar lifestyles of Maoris and Europeans in New Zealand, this low risk may have a genetic basis as appears to be the case for certain other ethnic groups. ${ }^{23}$

The results for non-Maoris in the northern and southern regions support the hypothesis that the occurrence of multiple sclerosis varies with latitude in New Zealand. One possibility that needs to be considered is that the estimated difference could have been exaggerated by the fact that Otago has had a Medical School for more than a century, whereas specialist services have been fully developed more recently in the Waikato. There are two reasons for believing that this has not had any major effect. First, the ratio of the incidence rates of multiple sclerosis in the last 5 years was almost identical to the ratio of the prevalence rates in the two regions. Secondly, the ageadjusted mortality rate from multiple sclerosis is $2 \cdot 1$ times higher in Otago and Southland than in the Waikato and adjacent region. ${ }^{22}$

The existence of a latitude effect in New Zealand is confirmed by regional analyses of two independent collections of data for the whole of New Zealand: mortality records and records of admissions to hospital for multiple sclerosis. ${ }^{822}$

Current theories about the aetiology of multiple sclerosis invoke both genetic and environmental factors. ${ }^{23}$ Could genetic factors account for the northsouth gradient in New Zealand? It is commonly held that the Scots are particularly susceptible to multiple sclerosis, although the evidence for a greater susceptibility than in other British people (independent of geography) is still limited. ${ }^{416}$ The proportion of people with Scottish ancestry is high throughout New Zealand, but it would be highest in the south. ${ }^{24}$ If one takes as a very crude index of Scottish ancestry the proportion of names beginning with "Mac" or "Mc" in the telephone directories of the four main cities, the proportion increases steadily from north to south.

There is increasing evidence that genetic susceptibility to multiple sclerosis is associated with the HLA system, ${ }^{2325}$ and it has been suggested that the high prevalence of the disease in Scottish people could be related to the frequency of certain HLA alleles. ${ }^{26-27}$ Studies are needed to determine the frequencies of relevant genetic markers in the north and south of New Zealand.

Although it is not yet clear whether genetic factors contribute to the gradient in multiple sclerosis risk with latitude in New Zealand, environmental factors are also likely to be important. In many parts of the 
world, studies of migrants have shown that the latitude effect is at least partly due to some acquired, exogenous influence. ${ }^{28}$

The multitude of possible environmental factors have been reviewed elsewhere. ${ }^{3429}$ Further work is needed to examine such hypotheses in the light of our findings in New Zealand, but some observations can already be made. The lifestyles of people living in the north and south of New Zealand are more closely similar than in many of the regions compared in the Northern Hemisphere. There is no appreciable gradient in affluence nor in standards of sanitation: 30 years ago, the proportions of households having piped water, baths or showers, and flush toilets were as high in the Auckland province (including the Waikato) as in Otago and Southland. ${ }^{30}$ This weighs against hypotheses based on analogy with enteric infections. ${ }^{29} 3132$ Perhaps studies of other childhood infections would be fruitful.

Climatic differences include higher average temperatures, sunshine hours, and humidity in the northern part of New Zealand. ${ }^{33}$ Regional comparisons of diet have not been published, but the consumption of porridge and root vegetables such as swedes would probably be higher in the south. Interest in dietary factors was stimulated by reports of international correlations between multiple sclerosis and cancer of the colon $^{34}$ and dental caries. ${ }^{35}$ Mortality from cancers of the colon and rectum appears to be elevated in the South Island, ${ }^{36}$ but before fluoridation the prevalence of dental caries was no higher in the south. ${ }^{37}$ Dietary and blood selenium levels are even lower in southern New Zealanders than in the north, ${ }^{38}$ but it is unlikely that this trace element plays any role in the aetiology of multiple sclerosis. ${ }^{39}$

New Zealand is a long country with an even standard of medical care. The variation in occurrence of multiple sclerosis offers excellent opportunities for research on the genetic and environmental determinants of this disease.

This research was supported by a grant from the Medical Research Council of New Zealand. We thank Mrs Judith Smeijers and Mrs Eileen Moore for their help throughout the project; Dr E D Acheson for advice in planning; Dr E W Willoughby for reviewing samples of cases from the two regions; $\mathrm{Mr}$ G F S Spears for data-processing; and the general practitioners and physicians who provided information about their patients.

\section{References}

1 Kurtzke JF. A reassessment of the distribution of multiple sclerosis. Acta Neurol Scand 1975;51:110-57.

2 Kurtzke JF. Geographic distribution of multiple sclero- sis: an update with special reference to Europe and the Mediterranean region. Acta Neurol Scand 1980;62:65-80.

3 Alter M. The geographic distribution of multiple sclerosis: new concepts. In: Bauer HJ, Poser S, Ritter G, eds. Progress in Multiple Sclerosis Research. Berlin: Springer-Verlag, 1980:495-502.

4 Acheson ED. The epidemiology of multiple sclerosis. In: McAlpine D, Lumsden CE, Acheson ED. Multiple Sclerosis: a Reappraisal. Edinburgh: Churchill Livingstone, 1972:3-80.

5 Detels R. Epidemiology of multiple sclerosis. In: Schoenberg BS, ed. Advances in Neurology, Vol. 19. New York: Raven Press, 1978:459-73.

6 McCall MG, Brereton TLeG, Dawson A, Millingen K, Sutherland JM, Acheson ED. Frequency of multiple sclerosis in three Australian cities - Perth, Newcastle, and Hobart. J Neurol Neurosurg Psychiatry 1968; 31:1-9.

7 Acheson ED. Multiple sclerosis in British Commonwealth countries in the Southern Hemisphere. $\mathrm{Br} J$ Prev Soc Med 1961;15:118-25.

8 Hornabrook RW. The prevalence of multiple sclerosis in New Zealand. Acta Neurol Scand 1971;47:426-38.

9 Cuningham JAK. The prevalence of disseminated sclerosis in Christchurch. NZ Med J 1972;76:417-8.

10 Allison RS, Millar JHD. Prevalence and familial incidence of disseminated sclerosis. Ulster Med J 1954;23 (suppl 2):5-23.

11 Alter M, Allison RS, Talbert OR, Kurland LT. Geographic distribution of multiple sclerosis. World Neurology 1960;1:55-68.

12 Department of Statistics. New Zealand Census of Populations and Dwellings 1981, Vol. 7, Birthplaces and Ethnic Origin. Wellington: Department of Statistics, 1983.

13 Schoenberg BS. Calculating confidence intervals for rates and ratios. Neuroepidemiology 1983;2:257-65.

14 Hyslop J, Dowland J, Hickling J. Health Facts: New Zealand. Wellington: Department of Health, 1983.

15 Stazio A, Paddison RM, Kurland LT. Multiple sclerosis in New Orleans, Louisiana, and Winnipeg, Manitoba, Canada. J Chronic Dis 1967;20:311-32.

16 Shepherd DI, Downie AW. A further prevalence study of multiple sclerosis in north-east Scotland. J Neurol Neurosurg Psychiatry 1980;43:310-5.

17 Massey EW, Schoenberg BS. International patterns of mortality from multiple sclerosis. Neuroepidemiology 1982;1:189-96.

18 Department of Statistics. New Zealand Official Yearbook 1985. Wellington: Department of Statistics, 1985: 94-107.

19 Miller H, Ridley A, Schapira K. Multiple sclerosis: a note on social incidence. Br Med J 1960;2:343-5.

20 Acheson ED. Epidemiology of multiple sclerosis. $\mathrm{Br}$ Med Bull 1977;33:9-14.

21 Smith AH, Pearce NE. Determinants of differences in mortality between New Zealand Maoris and nonMaoris aged 15-64. NZ Med J 1984;97:101-8.

22 Fawcett J. The Descriptive Epidemiology of Multiple Sclerosis in New Zealand. Dunedin: University of Otago, 1984. BMedSc Thesis.

23 McDonald WI. Multiple sclerosis: the present position. Acta Neurol Scand 1983;68:65-76. 
24 Olssen E. A History of Otago. Dunedin: John McIndoe, 1984.

25 Spielman RS, Nathanson N. The genetics of susceptibility to multiple sclerosis. Epidemiol Rev 1982;4:45-65.

26 Dick G. The etiology of multiple sclerosis. Proc $R$ Soc Med 1976;69:611-5.

27 Francis DA, Batchelor JR, McDonald WI, Hern JEC, Downie AW. Multiple sclerosis and HLA DQwl. Lancet 1986;1:211.

28 Kurtzke JF. Epidemiology of multiple sclerosis. In: Hallpike JF, Adams CWM, Tourtellotte WW, eds. Multiple Sclerosis. London: Chapman and Hall, 1983:47-95.

29 Alter M. Clues to the cause based upon the epidemiology of multiple sclerosis. In: Field EJ, ed. Multiple Sclerosis: a Critical Conspectus. Lancaster: MTP, 1977:35-82.

30 Department of Statistics. Population Census 1956, Vol. 9 , Dwellings and Households. Wellington: Government Printer, 1959:74-83.

31 Poskanzer DC, Schapira K, Miller H. Multiple sclerosis and poliomyelitis. Lancet 1963;2:917-21.

32 Dean G. Annual incidence, prevalence, and mortality of multiple sclerosis in white South-African-born and in white immigrants to South Africa. $\mathrm{Br}$ Med $J$ 1967;2:724-30.

33 Garnier BJ. The Climate of New Zealand. London: Edward Arnold, 1958.

34 Wolfgram F. Similar geographical distribution of multiple sclerosis and cancer of the colon. Acta Neurol Scand 1975;52:294-302.

35 Craelius W. Comparative epidemiology of multiple sclerosis and dental caries. J Epidemiol Community Health 1978;32:155-65.

36 Borman B. A Cancer Mortality Atlas of New Zealand. Wellington: Department of Health, 1982:25-41. (Special Report Series; No. 63.)

37 Hewat RET, Eastcott DF. Dental Caries in New Zealand. Christchurch: Medical Research Council of New Zealand, 1953:68-9.

38 Thomson CD, Robinson MF. Selenium in human health and disease with emphasis on those aspects peculiar to New Zealand. Am J Clin Nutr 1980;33:303-23.

39 Mazzella GL, Sinforiani E, Savoldi F, Allegrini M, Lanzola E, Scelsi R. Blood cells glutathione peroxidase activity and selenium in multiple sclerosis. Eur Neurol 1983;22:442-6. 